\title{
Trade Unionism and the Enhancement of Workers' Welfare in Nigerian Maritime Sector: An Empirical Analysis.
}

\author{
${ }^{1}$ Stephen Adi Odey, Ph.D, ${ }^{2}$ Emeka, Josephat Owan, Ph.D, ${ }^{3}$ Ogabor, John \\ Ofana \\ ${ }^{1,2}$ Department of Sociology University of Calabar, Nigeria \\ ${ }^{3}$ Federal College of Education, Obudu, Cross River State, Nigeria
}

\begin{abstract}
This study focuses on the influence of trade unionism and the enhancement of workers' welfare in Nigeria, using maritime workers' union of Nigeria as a case study. This relationship is analysed empirically, using the one-way analysis of variance and Pearson product moment correlation statistics were used to analyse the data. The findings showed that the level of negotiation adopted by union members exerts significant influence on workers' welfare. The study observed that the deprivation of workers from benefiting from their welfare package either by management or sometimes by ill-mannered union leaders was responsible for majority of the conflicts and strikes in work settings in our contemporary economy. Accordingly, trade unionism should be encouraged in all work settings and its leader vested with knowledge of industrial relations, union leaders should be individuals who seek after the welfare of its members and not their personal benefits.
\end{abstract}

\section{Introduction}

Trade unionism is a part of a wider concept - the labour movement - which consists of several more or less intimately related organizations such as labour parties, workers' mutual insurance organization, producers' and consumers' cooperative of improving the material, cultural and social status of their members.

A trade or labour union, according to Webbs (1920:1) "is a continuous association of wage - earners for the purpose of maintaining or improving the conditions of their employment".

Trade unions acts as monopolists in the labour market. They are permanent and continuing democratic organization voluntarily created by workers to protect themselves at their work and to improve their working conditions through collective bargaining, membership and education, political lobbying and campaigning etc and to provide an effective means of 'expressing workers' views on societal problem (Odey and Young 2008). They negotiate wages and working conditions and settle dispute (Gregorio 2004). They also provide forum through which collective bargaining is used primarily to secure improvements in workers' wages and conditions of service (Dalhatu 2007).

As Dalhatus (2007) noted, the economic pace in Nigeria is dilated of government and the large corporations - and the terms and conditions of service set by them not only influence them mutually, but also determine the standard which the small enterprise and the single employer must conform to or at least aim to attain. Fajana (1995) aptly remarked that while the single employer has always been economically stronger than the workers in terms of bargaining the terms of employment, the portion of the modern corporation and the state is even more overwhelming. This has emphasized the need today, even more than in the past, for workers to organ is as a means to effectively enhance their condition of employment.

\section{Theoretical Issues and Literature Review}

The literature on trade unionism is voluminous and hence separate with theories. These theories among others include: conflict theory, group behaviour theory and theory of relative deprivation. Essentially, the theory of relative deprivation more than any other theory explains the underlying attitude of organized labour that result into frequent strike actions in Nigerian industrial relations.

(a) Trade unions negotiations ability and enhancement workers welfare

(b) Collective bargaining

(c) Mandatory or negotiable issues

(d) Trade unions education of members and enhancement of workers welfare

\section{(a) Collective bargaining}

Collective bargaining is a term generally used as negotiation of working conditions and terms of employment between employers, a group of employers or one or more employers' associations on the one hand; and one or more representative workers organizations on the other, with a view to reaching agreement (Okere, 
2008). Reaching agreement is perhaps what makes negotiation equal to bargaining (Fajana, 2000). Otherwise, when negotiations go on endlessly without concrete agreement, no bargain could have been struck. The importance of this distinction becomes clearer when the bargaining situation in Nigeria's public service is focused. Using the definition of bargaining hereinbefore stated available evidence would tend to show that much that happens in the public service is described more as negotiation, and least as bargaining.

Adodo (2005) conducted a study on collective bargaining in formal organizations in Nigeria and concluded that the bargaining process represents negotiations on issues which both the trade union and the management have divergent position. He found that the process is based on the principle that workers have a right to contract with their employers as to wages and other conditions of service and that the employer recognize that right. In contrast to Adodo's position, Omole, Noah, and Powell (2006) conducted a state by state analysis of the impact of collective bargaining among teachers on workers performance. The result of their findings according to them shows that bargaining among workers and management does not have any significant effect on workers welfare as most agreements reached during collective bargaining are not implemented. They discovered that most union leaders sell out to management during negotiations.

Fashoyin (2003) pointed out that negotiation is concerned about improvement of workers welfare that will enhance their socio-economic status. In other words, the ability of union to negotiate issues that will directly lead to enhanced socio-economic status of their members in both social and economic activities without engaging on strikes will be satisfactory. This is taken to be the positive role of trade unionism.

\section{(b) Mandatory or negotiable issues}

It has been argued that no law explicitly specifies these issues, wage issues and a host of other conditions of employment are recognized by the Labour Act of 1974 as falling within the collective bargaining process. However, through custom and past practice, certain issues have become mandatory for negotiation. Table 1 provides a listing of such issues.

In recent times the heightened interest in negotiable issues is due partly to aggressive union pressure, as they seek to bring as many issues as possible within the ambit of negotiation (Dundon and Eva, 1998). Obviously, the more the number of issues in this category, the greater the chances of the union influencing the employment conditions of the employer(s). Consequently, issues that are slated for negotiation tend to be addressed by the employers (Fairbrother and Yates, 2003). Thus taking the above facts into consideration, negotiation should be accorded priority in the catalogue of welfare activities meant to enhance the socioeconomic status of workers.

Odah (2004) has similarly observed that the socio-economic enhancement of any worker depends, to a large extent on the ability of the unions to possess negotiating skills. He also argued that negotiation provides the arteries through which the welfare of workers flows.

TABLE 1

Mandatory or negotiable issues, 1982

\begin{tabular}{llll}
\hline \hline 1. & Wages and salaries & 2. & Hours of work \\
3. & Sick leave & 4. & Out of station allowance \\
5. & Shift and night allowance & 6. & Leave allowance \\
7. & Annual leave & 8. & Transfer allowance \\
9. & Housing allowance & 10. & Redundancy (principle) \\
11. & Acting allowance & 12. & Pension and gratuity \\
13. & Disciplinary procedure & 14. & Annual cash payment \\
15. & Uniform/protective clothing & 16. & Medical scheme \\
17. & Extra duty allowance & 18. & Canteen facilities \\
19. & Overtime rates & 20. & Heat allowance \\
21. & Maternity leave & 22. & Transport allowance \\
23. & Long service award & 24. & Transport facilities \\
25. & Car/motor-cycle allowance & & \\
\hline \hline
\end{tabular}

Source: $\quad$ Fashoyin, T. (1982) "Emerging Trends in Collective Bargaining in Nigeria" Perman, (January 12).

Negotiation therefore, within the economic framework is vital to progress, peace and harmony in our industrial relations.

The work place is becoming increasingly important as a site for workers to acquire skills and qualifications, and enhance employment (Payne, 2001). However, for some, access to learning opportunities in the work place is uneven, whilst for others the opportunity to strengthen the ability to find/or sustain employment through workplace education is simply not available. Trade unions have long been concerned with 
education and learning, particularly with regard to membership education and the education of members and employees. (Bridgeford and Stirling, 2002). From whatever angle we look at it, workers' education, according to Bacon and Blyton (2000) deals primarily with educational needs of workers as they arise out of their participation in labour movement.

\section{c) Trade Unions education of members and enhancement of workers' welfare}

The work place is becoming increasingly important as a site for workers to acquire skills and qualifications, and enhance employment (Payne, 2001). However, for some, access to learning opportunities in the work place is uneven, whilst for others the opportunity to strengthen the ability to find or sustain employment through workplace education is simply not available. Trade unions have long been concerned with education and learning, particularly with regard to membership education and the education of members and employees (Bridgeford \& Stirling, 2002). According to Bacon and Blyton (2000) workers' education deals primarily with educational needs of workers as they arise out of their participation in labour movement.

Fairbrother and Yates (2008) recent review of workers' education discovered that the objective of workers' education in the improvement of workers individual and group competence, and the advancement of his social, economic and cultural interests.

Omole (1983) is of the opinion that workers' education is that kind of educational activities which seek to provide workers with the equipment that will help them develop fully their individualities and enable them to fulfill more adequately their trade union and related functions and to participate more effectively in the economic and social life of modern society.

\section{Methodology and Data Analysis}

In order to undertake an in-depth investigation of trade unionism and the enhancement of workers' welfare in the maritime sector, the study adopts the survey method anchored basically on questionnaires and interviews as means of data collection. This technique is preferred because it is oriented toward the determination of the status of a given phenomenon.

The population of this study comprises of maritime workers in Eastern Ports of Nigeria. Eastern Ports are made up of Calabar, Port Harcourt, Warri, and Onne and statistics available at the headquarters of the parts showed that there were four thousand, one hundred and ten (4110) workers in all Eastern parts of Nigeria as at the time of this study. Sample size per port was decided based on the number of workers per port.

Table 2

Maritime workers in eastern ports, Nigeria (2009 - 2011)

\begin{tabular}{llcc}
\hline \hline S/N & Name of port & No. of Workers & \% \\
\hline \hline 1 & Calabar & 1.958 & 47.64 \\
2 & Port Harcourt & 935 & 22.75 \\
3 & Warri & 730 & 17,76 \\
4 & Onne & 487 & 11,85 \\
& Total & 4110 & \\
\hline \hline
\end{tabular}

Source: NPA statistics department 2009

\section{Methodology and Data Analysis}

In order to undertake an in-depth investigation of trade unionism and the enhancement of workers' welfare in Eastern Ports, the survey research method was adopted.

The population of this study comprises of Maritme workers in Eastern Parts of Nigeria. Eastern Ports are made up of Calabar, Port Harcourt, Warri and Onne Ports and statistics available at the headquarters of the ports show that there were four thousand, one hundred and ten (4110) workers in all Eastern Ports of Nigeria as at the time of this study. Sample size per port was decided based on the number of workers per port. After deciding the sample per port, the workers in each port were categorized into male and female to enable the researcher select a representative sample taking into consideration the respondents' sex using purposive sampling method.

The sample of this study was made up of one thousand (1000) respondents selected from the four Eastern Ports of Nigeria. Of this sample 650 workers $(65 \%)$ were male and 350 workers (35\%) were female. The questionnaire was divided into two sections. Section A had to do with the respondents bio-data or demographic information such as sex, age, educational qualification, position and salary scale. Section B was made up of forty five (45) items on a four-point scale measure that sought workers' opinions on the five independent sub-variables (namely union's negotiation of workers' welfare, unions' education of members, union's leadership training, and the four dependent variables (namely award of scholarships to member's 
children, festivity packages, soft loans to members and financial assistance). Each independent variable had six items while the dependent variable (workers welfare) had four items on the questionnaire.

\section{Testing of Hypotheses}

Three (3) hypotheses were generated in order to achieve the research objectives. The study sought to determine the relationship between trade unions' negotiation, enhancement of workers' welfare, influence of trade unions' education of members and trade unions' leadership training on enhancement of workers' welfare.

\section{Hypothesis one}

In the null form, this hypothesis stated that there is no significant influence of trade union's negotiation on the enhancement of worker's welfare. In this hypothesis, the independent variable is the measure of union's extent of negotiation. This was assigned three independent levels (high, moderate and low). The dependent variable is workers' welfare. This was measured continuously in this study. In other words, the mean score $(\bar{X})$ and standard deviation (SD) of those who see union's negotiation ability to be high, moderate and low were obtained and compared in terms of the welfare they derive from the union respectively. This demands that oneway ANOVA be employed in the analysis.

The calculated F-value representing the observed influence of trade union's negotiation on workers' welfare is 4.29 . This was found to be greater than the critical F-value of 3.00 at 0.05 level of significance with 2 and 997 degrees of freedom. On the basis of this, the null hypothesis was rejected while the alternate hypothesis is accepted. The interpretation of this is that the extent to which the union is engaged in negotiation has a direct or significant influence on workers' welfare.

TABLE 3

One-way analysis of variance of the influence of trade union's negotiation on the enhancement of workers' welfare

\begin{tabular}{lcccc}
\hline \hline Group & Extent of Negotiation & $\mathbf{N}$ & $\bar{X}$ & SD \\
\hline \hline 1 & High & 237 & 29.86 & 3.38 \\
2 & Moderate & 401 & 28.9 & 5.41 \\
3 & Low & 362 & 27.22 & 6.63 \\
Source of variation & SS & Df & Ms & F \\
Between groups & 79.65 & 2 & 39.83 & $4.29^{*}$ \\
Within groups & 9282.07 & 997 & 9.31 & \\
Total & $\mathbf{9 3 6 1 . 7 2}$ & $\mathbf{9 9 9}$ & & \\
\hline \hline
\end{tabular}

$*$ P<.05, $\mathrm{df}=2$ and 997, critical $\mathrm{F}=3.00$

Given the significant F-value of 4.29 , it became necessary to carry out a detailed multiple comparisons to determine exactly which of the pairs of level of negotiation (high, moderate and low) differ significantly from each other in terms of influence on workers' welfare. This was done using Fishers' Least Significance Difference (LSD) Post Hoc test.

From the calculation, significant t-values are observed between groups 1 and 2 , and 2 and 3 and also $t-$ values are greater than the critical t-value of 1.96 at 0.05 level of significance with 998 degree of freedom. This means that the groups of respondents are respectively different from one another irrespective of their perception of union's extent of negotiation.

TABLE 4

Result of Fishers' least significance difference test of the workers' welfare

influence of union negotiation on

\begin{tabular}{llccc}
\hline \hline Group & \multicolumn{1}{c}{$\begin{array}{c}\text { Extent of } \\
\text { Negotiation }\end{array}$} & $\begin{array}{c}\mathbf{1} \\
(\mathbf{n}=\mathbf{2 3 7})\end{array}$ & $\begin{array}{c}\mathbf{2} \\
(\mathbf{n}=\mathbf{4 0 1})\end{array}$ & $\begin{array}{c}\mathbf{3} \\
(\mathbf{n}=\mathbf{3 6 2})\end{array}$ \\
\hline \hline 1 & High & $29.86^{\mathrm{a}}$ & $1.77^{\mathrm{b}}$ & 2.64 \\
2 & Moderate & $7.08^{*^{\mathrm{c}}}$ & 28.09 & 0.87 \\
3 & Low & $10.35^{*}$ & $3.93^{*}$ & 27.22 \\
& & $\mathbf{9 . 3 1}$ & & \\
\hline \hline
\end{tabular}

(a) Group means are on the diagonal

(b) Difference between group means are above the diagonal 
(c) Fishers' least significance difference test values are below the diagonal

$* \mathrm{P}<.05, \mathrm{df}-998$, critical $\mathrm{t}=1.96$

\section{Hypothesis two}

It states that there is no significant influence of union's education of members on worker's welfare.

Unions' education of members is the independent variable of this hypothesis. This was assigned three independent levels depending on the amount of education accorded members by the union. It was operationally seen to be either high, moderate or low. The classification was based on the mean scores obtained by the respondents on the variable. The dependent variable on the other hand (workers' welfare), was measured continuously. Since the independent variable was categorized into the three groups and compared on a dependent variable that was measured continuously, one-way analysis of variance (ANOVA) was considered the most applicable test tool for its analysis.

The influence of union's education of members represented by the calculated F-ratio of 5.58. This is found to be greater than the critical F-value of 3.00 at 0.05 level of significance with 2 and 997 degrees of freedom.

TABLE 5

One-way analysis of variance of the influence of union's education of members on workers' welfare

\begin{tabular}{lcccc}
\hline \hline Group & Education of members & $\boldsymbol{n}$ & $\bar{X}$ & SD \\
\hline \hline 1 & High & 329 & 29.97 & 4.39 \\
2 & Moderate & 381 & 28.66 & 5.02 \\
3 & Low & 290 & 28.41 & 5.63 \\
Source of variation & SS & df & $M$ s & F \\
Between groups & 92.42 & 2 & 45.21 & \\
& & & & $5.58^{*}$ \\
Within groups & 8255.16 & 997 & 8.28 & \\
Total & 8347.58 & 999 & & \\
\hline \hline
\end{tabular}

$* \mathrm{P}<.05, \mathrm{df}=2$ and 997, critical $\mathrm{F}=3.00$

Based on this, the null hypothesis is rejected while the alternate is accepted. This means that union's education of members exerts significant influence on workers welfare.

To determine exactly where the difference lies or what amount of education exerts more influence on members' welfare than the other, a post hoc comparison test was considered necessary. This was carried out using Fisher's least significant difference (LSD) test. The result obtained are presented in Table 5.

As shown in Table 5, differences among groups exists between group 1 and 2 and between groups 1 and 3. In each case, significant $t$-value of 6.05 and 6.73 were obtained.

These were respectively greater than the critical t-value of 1.96 at 0.05 level of significance with 998 degree of freedom. However, the difference between groups 2 and 3 is observed not to be significant. This means that high and moderate education of members bring better workers' welfare than when members have low education.

TABLE 6

Fishers least significant difference post hoc test of the influence of union's education of members on workers' welfare

\begin{tabular}{clccc}
\hline \hline Group & \multicolumn{1}{c}{$\begin{array}{c}\text { Education of } \\
\text { members }\end{array}$} & $\begin{array}{c}\mathbf{1} \\
(\mathbf{n}=\mathbf{3 2 9})\end{array}$ & $\begin{array}{c}\mathbf{2} \\
(\mathbf{n = 3 8 1})\end{array}$ & $\begin{array}{c}\mathbf{3} \\
(\mathbf{n = 2 9 0})\end{array}$ \\
\hline \hline 1 & High & $29.97^{\mathrm{a}}$ & $1.31^{\mathrm{b}}$ & 1.56 \\
2 & Moderate & $6.05^{* \mathrm{c}}$ & 28.66 & 0.25 \\
3 & Low & $6.73^{*}$ & 1.11 & 28.41 \\
& & & & \\
\hline \hline
\end{tabular}

(a) Group means are on the diagonal

(b) Difference between group means are above the diagonal 
(c) Fishers' LCD test values are below the diagonal

$* \mathrm{P}<.05, \mathrm{df}=998$, critical $\mathrm{t}=1.96$.

In other words, the difference is brought about by groups 1 and 2 .

\section{Hypothesis three}

In the null form, the third hypothesis stated that there is no significant influence on union's leadership training on workers welfare. The independent variable (union's leadership training of members) was assigned three independent levels. In other words, respondents were categorized on the basis of the amount of leadership training received in their organizations. These categories were compared on the basis of the welfare they benefit from the union which is the dependent variable. Since the independent variable is categorical (with three levels) and the dependent variable was measured continuously, one-way analysis of variance was used to compare the mean score $(\bar{X})$ and standard deviation (SD) of the groups of respondents in terms of welfare. Detail of the analysis is as summarized and presented in Table 7.

TABLE 7

Result of one-way analysis of variance of the influence of union's leadership training on workers' welfare

\begin{tabular}{lccccc}
\hline \hline Group & Extent of training & $\boldsymbol{n}$ & $\bar{X}$ & SD \\
\hline \hline & High & 329 & 28.96 & 5.21 \\
& 1 & Moderate & 318 & 29.08 & 4.69 \\
3 & Low & 353 & 28.84 & 5.14 \\
Source of variation & SS & df & $M$ s & F \\
Between groups & 63.71 & 2 & 31.86 & \\
Within groups & & & & & 2.89 \\
& & 10986.94 & 997 & 11.02 & \\
\hline \hline
\end{tabular}

$* \mathrm{P}<.05, \mathrm{df}=2$ and 997, critical $\mathrm{F}=3.00$.

As shown in Table 6, the calculated F-value is 2.89 . This represents the observed training on workers' welfare. The calculated F-ratio was found to be less than the critical F-value of 3.00 at 0.05 level of significance with 2 and 997 degrees of freedom. Thus, the null hypothesis was retained while the alternate hypothesis was rejected. The interpretation of this is that the amount or extent of leadership training accorded union members does not influence the welfare they derive from the union.

\section{Discussion of Findings}

The first hypothesis explored the possible influence of union's negotiation ability on the enhancement of workers' welfare. Union's negotiation was operationalized to have three levels (high, moderate and low). From the analysis of the data obtained, it was found that the extent of union's engagement in negotiation exerts significant influence on workers' welfare. The higher the negotiation ability, the better the welfare derived. This is made clearer when one looks at the mean scores of the three categories of respondents in their measurement of workers' welfare. Those who see high extent of negotiation perceived high measure of workers welfare than those who see moderate extent of negotiation. The mean score of the second group is also higher than that of the third group. In short, the mean scores were 29.86, 28.09 and 27.22 respectively. By implication, this findings show that workers' welfare is significantly tied to the extent on which union's leaders are able to negotiate with management, the better the welfare and vice versa.

As noted here, this finding is contrary to that of Omole, Noah and Powell (2006). The results of their study showed that the level of bargaining among workers and management does not have any significant effect on workers' welfare. Giving reason for this, they assert that most agreements reached with management during collective bargaining are not implemented as most union leaders are scandalously bought over by management during negotiations.

The analysis of data obtained to test the second hypothesis of this study showed that there is a significant influence of union's education of members on workers' welfare. Due to this finding, the null hypothesis was rejected. Details of the analysis using Fishers LSD post hoc test shows a significant difference between members who have low education and others. In other words, the categories of workers with high and 
moderate education have higher record of workers' welfare (29.97 and 28.66) than those with low education (28.41).

The analysis of data obtained to test the secured hypothesis of this study showed that there is a significant influence of Union's education of members on workers' welfare. The implication of these findings is that education of union members is a veritable vehicle for the attainment of good welfare status. In other words, when union members are given high level of education, it exposes them in a way to better and tenable ways of fighting for and protecting their rights both as workers and as citizens. This findings also agrees with the position of Baton and Blyton that education leads to the competence and the advancement of workers' social, economic and cultural interest so that he/she can become a 'mature', wise and responsible citizen.

From the analysis of the data obtained to test the third hypothesis of the study, it was gathered that union's leadership training does not exert any significant influence on workers' welfare. Thus, the null hypothesis was accepted.

The implication of this is that whether union leaders are given high, moderate or low leadership training, it does not affect the benefit or welfare that accrues to members. This can also be interpreted to mean that there is no significant relationship between union's leadership training and workers welfare.

The finding from the third hypothesis that there is no significant influence of union's leadership training lends credence to the works of Peretomode (2003) who found that irrespective of the leadership training received, most leaders in organizations are production-centred and lay more emphasis on rigid work standards, employees' tasks and methods used to accomplish them and closely supervised their subordinates work, without considering the welfare of the staff.

Furthermore, Peretomode (2003) submitted that workers who are exposed to training eventually become leaders of departments and units. In such units and departments, the sole concern of the leader is in higher productivity and not the welfare of the workers.

Similarly, this finding agrees with that of Bale (1999) who found out that leaders who are regularly trained tended to be more innovative, productive and participative than those who do not embrace training programmes. Even though such leaders have higher outputs compared to their counterparts with less training, they are not significantly better in terms of bringing about welfare to workers.

Contrary to this finding is the submission of Beach (1975) that a well trained leader is always focused and ensures good relationship with workers under him. When this is ensured, there is no denying the fact that workers welfare will equally be taken into consideration. Further, Beach argued that one of the reasons why some leaders fail and why there are conflicts in most work settings is because they lack training. This deficiency according to Beach, results in their not being abreast with recent developments, thereby leading to low productivity on the part of workers. Put differently, when leadership training is accorded individuals, it will have a positive effect on both the production capacity of the organization involved as well as on the self-esteem, selfworth and or welfare status of the workers.

\section{Conclusion}

Trade unionism in Nigeria has helped to bring about higher nominal wages in the modern sector through independent commissions but despite the carefully constructed institutional framework and the vowed commitment of all parties concerned, voluntary collective bargaining has failed to function as a significant mechanism for fixing wages, implying defective collective bargaining in Nigeria.

However, it is clear from this study, that workers welfare is influenced by some factors including level of negotiation, and union's education of members. Skillful and well educated union leaders can make a great difference to the effective management of labour demands. The enormous face-up or conflicts observed between management and workers is due to the fact that union leaders are not living up to their responsibilities in terms of engaging in high level of responsible negotiation with management, education of members to know their rights in the organizations.

\section{Recommendations}

These findings points to an important fact: the welfare situation of workers in the Nigerian maritime sector needs more attention from all stakeholders - the government, the Union and the workers themselves. Accordingly workers in the maritime sector should ensure that:

(1) Union leaders should only be persons with high ability to negotiate with management for welfare of its members and not individuals who will compromises the Union's stand on personal benefits.

(2) Union leaders should ensure the education of members. This can be done through the organization of seminars and workshops for its members, which will enhance their knowledge and conflicts in work settings reduced to the bearest minimum.

(3) Trade unionism should be encouraged in all work settings and its leaders should be vested with knowledge of industrial relations. 


\section{References}

[1] Adodo, D. A. (2005). An overview of the New Labour Act 2005 and its impacts on labour movement in Nigeria. A paper presented at the conference of Senior Staff Association of Nigeria (SSANU), University of Ibadan, Ibadan. June, 15.

[2] Bacon, N. \& Bylton P. (2004). Trade union responses to workplace restructuring: Exploring union orientations and actions. Work, employment and society, 18 (4), 749-73.

[3] Beach, J. A. (1975). Trade Unionism: London: Coller - Macmaklan.

[4] Bridgeford, J. \& Stirling, J. (2002) Trade union education in Europe. Brussels: ETUCO.

[5] Dalhatu, M. B. (2007). Public servants, trade unions and industrial relations in Nigeria. Nigerian Journal of Labour Law and Industrial Relations 1(2), 21-25.

[6] Dundon, T. \& Eva, D. (1998). Trade Unions and bargaining for skill. Employees Relations, 20 (1), 57-72

[7] Fairbrother, P. \& Yates, C. A. (2003). Trade union in renewal: A comparative study of trade union movements in five countries continuum. London: Lapi Publishers.

[8] Fajana, S. (1995). Industrial relations in Nigeria. Lagos: Danaf Press.

[9] Fashoyin, T. (2002). National level social dialogue: Global trends and implications for Nigeria. A seminar paper organized for Nigeria Ports Authority Staff. Otta, August 12.

[10] Gibson, H. \& Donelly, K. (1999). Globalization and challenges of employment. Kaduna: Abaam publishers

[11] Gregorio, H. (2004). Coaching participants on negotiation skills. At www.gebillikopf@ucdavis.edu. Retrieved on $24^{\text {th }}$ February, 2009.

[12] Martin, D. (1996). Building capacity, caring and craft Canadian Association for Adult Education conference, Winnipeg, June 7.

[13] Odah, J. Z. (2004). Trade union education: The Nigerian experience. A seminar paper for the officials of the Nigerian Labour Congress, Lagos. April 15.

[14] Odey, S. A. \& Young A. (2008). An appraisal of the trade unions (amendment) act 2005: Implications and challenges for effective bargaining and industrial conflict resolution. Nigerian Journal of Labour Law and Industrial Relations, 2 (2), 81-91.

[15] Offiong, D. A. (1983). Organized labour and political development in Nigeria. Calabar: Centaur Press.

[16] Okere, O. V. (2008). Collective bargaining, strike and the quest for industrial peace in Nigeria. Journal of Labour Law and Industrial Relations, 2 (2), 39-66.

[17] Omole, M; Noah, S. \& Powell, H. (2006). Deregulation of bargaining in Nigeria: Problems and Prospects. African Journal of Labour Studies, 25(1), 1-12.

[18] Onitiri, S. (2003). Transportation and workers productivity in the maritime sector. A Paper presented at Mills seminar for Nigerian Ports Authority unionists, Ijebu, December, 8.

[19] Payne, J. (2001). Lifelong learning: A national trade union strategy in a global economy. International Journal of Lifelong Education, 20(5), 378-92.

[20] Peretomode, V. (2003). Educational administration: Applied Concepts and theoretical perspectives for students and practitioners. Lagos: Joja Educational Research and Publishers. 